\title{
BLADE WEAPON AS A PART OF AN EQUIPMENT OF THE MERCENARIES OF THE KINGDOM OF POLAND IN THE SECOND HALF OF THE $15^{\mathrm{TH}} \mathrm{C}$.
}

\begin{abstract}
Sources from the second half of $15^{\text {th }} \mathrm{c}$. contain a lot of information about arming of mercenaries of Kingdom of Poland. Those materials are located in the Central Archives of Historical Records in Warsaw. Those are mostly lists of taken soldiers with weapons and also lists of weapons lost during war campaigns. Mentions about blade weapon are found in records from the period of the Thirteen Years' War with Teutonic Order (1454-1466). Most of the information concerns infantry, only in records from 1471, 1880 soldiers were recorded to have been using blade weapon. According to the analysis, the most popular blade weapons were swords - used by $51 \%$ of infantryman. Slightly fewer was the number of used sabers $-47 \%$ of soldiers used them in 1471 . Sometimes mercenaries were equipped in falchions, estocs, daggers and sharshoons - which is the name for heavy sword. Sources concerning cavalry blade weapon occurs very rarely. According to those few mentions it can only be told, that horseman used both swords and sabers.
\end{abstract}

Keywords: Kingdom of Poland, Middle Ages, mercenaries, blade weapon, armour

Blade weapons, such as swords, sabres, estocs, falchions and daggers were basic elements of an equipment of a medieval soldier. Materials documenting service of mercenary troops of the Kingdom of Poland in the years 1471-1500 are stored in Central Archives of Historical Records in Warsaw ${ }^{1}$. From this period, most information about mercenaries' weaponry is included in registers drawn up by the royal official during the inspection of the unit enrolled in the armed services. These lists provide names of individual soldiers and information about their weaponry. They were necessary to receive a payment and compensation for the weapons lost during the war. However, in these registers, in principle, blade weapons were ignored. From the point of view of the official preparing the lists, information on this weapon was not important, because - unlike in case of the rest of the equipment - if a soldier lost his blade weapon, he was not entitled to receive compensation. Of all the surviving registers of infantry, those from 1471, in which blade weapon was present, are an exception. A total of 1880 soldiers with blade weapon was reported (see table). Cavalry registers from the same year did not include blade weapon. Information on providing soldiers with blade weapons does not only allow to tell what types of weapons were used, but also indicates popularity of different types of weapons. Apart from troops' registers, lists of lost weapons inform of mercenaries' weapons as well. Blade weapons

Senkowski 1954, 497-521. appear in them not very often. Such mentions have auxiliary character, because they confirm the fact that soldiers were equipped with this kind of weapon, even though it was not present in the registers. There are also sources that mention mercenaries buying blade weapon in order to bolster their equipment.

\section{Swords}

The swords owned by paid riders were mentioned very rarely in the $15^{\text {th }} \mathrm{c}$. Some records are included in the information about payments for, among others, weapons lost by marcenary riders in the service of the Prussian Confederation during Thirteen Years' War (1454-1466) ${ }^{2}$. Other records of swords are present in the inventory of horses and weapons lost by mercenary riders who were in Polish military service in 1471 . Sources concerning infantry contain much more references to swords. Records from 1471 showed that sword was a part of equipment of 961 infantrymen, i.e. $51 \%$ of the total. Mentions of swords are usually brief and, except for a few, do not provide any additional information about listed weapons. This is not surprising, because swords of mercenary infantry did not differ much from each other. Although it was proven that at the end of the $15^{\text {th }}$ c. 12 different types of swords were in use, a fundamental difference between them was their length ${ }^{3}$. However, in terms of length, infantry's weapon was less 
diverse than the riders' one. As we know from iconography, in Poland, blade weapon was kept primarily strapped to the waist, thus the length of a typical infantryman's sword could be approximately 1,2 m. Mentions containing additional information about swords can be only occasionally found in registers. In the registry of Wacław's troop there were recorded two swords, which were classified as good - it meant they were better than average ones ${ }^{4}$. In turn, in Bartosz's troop served crossbowman, whose sword was broken. Another soldier had rusty sword (rdzivy). Royal official conducting an inspection had reservations about the sword of a man named Janthas from Jan Machna's troop. The writer described his weapon as bad, we do not know why this weapon deserved such a negative assessment ${ }^{5}$.

\section{Sharshoon}

The registers of infantry from 1471 include a weapon called a sharshoon (szarszun $)^{6}$. The oldest known mention of this weapon in Polish sources comes from 1444. Besides records, it appears in the sources always as vague variation of the sword: gladius alias scharschan ${ }^{7}$. The weapon remained in use in the $16^{\text {th }} \mathrm{c}$. Sharshoon was recorded twice in the description of weapons of soldiers escorting supply wagons sent to the war with the Teutonic Order in $1521^{8}$. It is also mentioned by Polish Renaissance poet Mikołaj Rej of Nagłowice (1505-1569), who recognizing the existence of different characters of people wrote: one wants a farm, another a horse and a sharshoon ${ }^{9}$. Thus, it can be concluded that the sharshoon could have also been used by riders. However, it must be taken into consideration that the poet could have used here a figure of speech not entirely reflecting the reality. The cost of sharshoon was 24-30 groses, so it did not differ much from swords or sabers ${ }^{10}$. In the older literature one can find different interpretations of the word sharshoon. Kazimierz Władyslaw Wójcicki, the nineteenth-century researcher of military history, explaining the concept of ,szarszun" recognized it as a weapon that the nobility hung every day at their side while leaving the house $e^{11}$.

In later studies, we come across a statement that this is an old Polish name for an estoc ${ }^{12}$. Specialized Old Polish Dictionary says that a sharshoon is a long sword. Similar, though more precise explanation of meaning of sharshoon is provided by Czech literature. In this language it is known as sarsoun, i.e. two-handed sword, which at the end of the

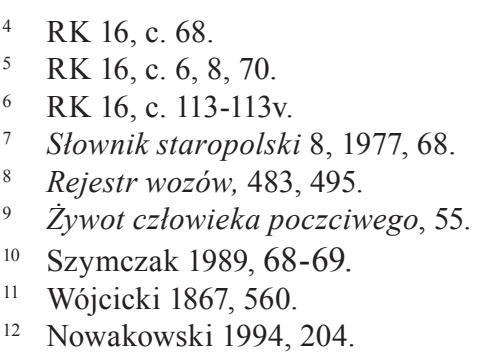

Middle Ages was used by the Swiss and Landsknechts ${ }^{13}$. The analysis of mentions of sharshoons included in registers precludes translating this name as a sword or an estoc. Both of these types of weapons appear in the lists of infantry as well as sharshoons, thus an official who prepares troop's register distinguished the weapons from each other assigning them appropriate names. Although together with swords sharshoons are also reported, designation sword i.e sharshoon (gladius alias scharschan) - cited above and appearing in sources repeatedly - allows to assume that sharshoon is a type of a sword. The period in which sharshoon exists in sources, is the time when plate armor was in full bloom. Confronted with such an armor, previously used swords were of little use. Swordsmiths began research that led to creation of a heavy sword with a massive blade that could inflict cutting blows, which allowed to damage opponent's armor ${ }^{14}$. It is worth mentioning the record from 1471, concerning Jakub called an Englishman, a soldier of the captain (=rothmagister) Mark's troop. The infantryman was recorded in the registry as armed with a crossbow and myeczysko ${ }^{15}$. In Polish, mieczysko can mean a big or old sword, so it could have been an identical weapon to the ones occurring in other sharshoons' lists. Sharshoons are mentioned in five registers of mercenary infantry. A total of 16 soldiers armed with this weapon was recorded there and, what is interesting, among them were both crossbowmen and pavis-bearers. In the register of captain Niemczycki's troop there were listed, apart from soldiers armed with swords and sabres, five soldiers with sharshoons and one with an estoc. It was similar in captain Piotr's registry. His troop consisted of a dozen horse riders and a group of infantrymen. 8 sharshoons and 2 falchions were a part of their melee weapon. In other troops there are single sharshoons ${ }^{16}$. There are no mentions of sharshoons in other registers. It can not be ruled out that this type of sword appeared as well in equipment of mercenaries in other troops. It could have been, however, classified in the registers as a regular sword (Tab. 1).

\section{Sabre}

The sabre was the most popular melee weapon in Poland the $16^{\text {th }}-18^{\text {th }} \mathrm{c}$. It was, however, well-known and quite often used by combatants already in the Middle Ages. The increase in popularity of this weapon in Europe took place in the $14^{\text {th }} \mathrm{c}$. This was due to more frequent contacts with Turkey, where sabres were in common use. The sabre started gaining many enthusiasts first in Hungary and then in Poland ${ }^{17}$.

\footnotetext{
13 Masaryki̊v slovník naučný 1939, 15.

14 Szymczak 1998, 233.

15 RK 16, c. 103v; Górski 1893, 218.

16 RK 16, c. 106-107v.

17 Nadolski 1984, 83-84; Głosek 1992, 64. See: Kwaśniewicz 1988.
} 


\begin{tabular}{|c|c|c|c|c|c|c|c|c|}
\hline No. & Captain & Sword & Sharshoon & Sabre & Estocs & Falchion & Dagger & Sum \\
\hline 1 & Bartosz & 42 & - & 41 & 1 & - & - & 84 \\
\hline 2 & Groti Matysz & 70 & 1 & 96 & 1 & - & 1 & 169 \\
\hline 3 & Grzegorz Składny & 37 & - & 56 & 2 & - & - & 95 \\
\hline 4 & Jaksa & 13 & - & 14 & - & - & - & 27 \\
\hline 5 & Jan Machno & 20 & - & 27 & - & - & - & 47 \\
\hline 6 & Stanisław Łojek & 40 & - & 45 & - & - & 1 & 86 \\
\hline 7 & Marek & 243 & - & 195 & 1 & 1 & 1 & 441 \\
\hline 8 & Mikołaj Brożyna & 35 & - & 23 & 1 & 1 & 1 & 61 \\
\hline 9 & Niemczycki & 31 & 5 & 44 & 1 & - & - & 81 \\
\hline 10 & Ocharek & 37 & - & 39 & 1 & 10 & - & 77 \\
\hline 11 & Piotr & 18 & - & 28 & 2 & 18 & 5 & 62 \\
\hline 12 & Maciej Pławecki & 14 & - & 17 & - & - & - & 31 \\
\hline 13 & Ścibor and Janecki & 45 & - & 39 & - & 31 & - & 88 \\
\hline 14 & Ścibor and companions & 73 & - & 42 & - & 11 & - & 117 \\
\hline 15 & Wacław & 133 & - & 34 & - & - & - & 167 \\
\hline \multirow[t]{2}{*}{16} & Jan Cieniecki & 110 & - & 135 & 1 & 1 & - & 247 \\
\hline & SUM & 961 & 16 & 875 & 10 & 9 & 9 & 1880 \\
\hline
\end{tabular}

Tab. 1. Blade weapon in registers of mercenary infantry from 1471. Elaborated by T. Grabarczyk.

There is only one known late medieval sabre coming from Polish territories. It was found in the bottom of the river Narew in Pułtusk ${ }^{18}$, now stored in the Museum of Mazovian Gentry in Ciechanów. The weapon survived in relatively good condition. The total length is $108 \mathrm{~cm}$, of which blade measures $89,5 \mathrm{~cm}$ and is $3,5 \mathrm{~cm}$ wide, crossguard $-28 \mathrm{~cm}$, and pommel is $3,5 \mathrm{~cm}$ high and $4 \mathrm{~cm}$ wide. The blade is slightly curved, ended with two-edged yelmen. Sabre is equipped with a handle typical for swords. It is dated to the second half of the $15^{\text {th }}$ c. ${ }^{19}$ (Fig. 1). Sabre occasionally appears also in Polish medieval iconography. This type of weapon was shown in the triptych of the Coronation of Madonna (circa 1460) of the collegiate church in Wieluń, in the scene of capture in the polyptych in the collegiate church in Kalisz (circa 1500) and in the figure of the Balthasar Behem Codex (1505) showing swordsmith's workshop in $\mathrm{Cracow}^{20}$.

The oldest record of the sabre in Polish written sources dates back to $1464^{21}$. Chronologically, the following information about the weapon dates back to 1471 and can be found in the records of mercenary troops. In written sources sabre was refered to in Latin as cutler or framea. Already in the $70 \mathrm{~s}$ of the $15^{\text {th }} \mathrm{c}$., Polish term szabla (=sabre) was commonly used. Both the weapon itself, and the sound of its Polish name - szabla indicate that the weapon came to

\footnotetext{
18 Pułtusk - town situated $50 \mathrm{~km}$ North from Warsaw.

19 Głosek 1992, 63.

20 Głosek 1998, 34.

21 Szymczak 1989, 53-34; Głosek 1998, 33-34. See as well:
} Nadolski 1954.
Poland from Hungary, where it exists as szeble, szablya and zablya. In written sources remained records of the prices of sabres which suggest that in the second half of the $15^{\text {th }} \mathrm{c}$. this weapon usually cost 20 to 30 groses. As far as information on the equipment of Polish mercenaries is concerned, there remained only one record. The list of weapons lost during Polish expedition to the in 1471 informs of 4 sabres. First belonged to lightly armoured rider named Białkowski. Second one was lost by the mercenary nicknamed Balwierz, another one by one of the members of the retinue of heavily armed soldier Bartosz (=Bartholomew). Final record concerns a man named Ysztwan, whose name suggests his Hungarian origin. He was also a lightly armed rider. To sum up, none of the aforementioned sabres was a part of a heavily armed rider's equipment. A small number of references to melee weapon used in cavalry does not allow to determine the actual condition of the equipment. However, the fact that sabres appear in the lists of the lost weapons more often than other types of melee weapon suggests that it was a weapon popular among riders.

Much more information about sabres can be found in records of mercenary infantry. According to the register of infantrymen signed up in 1471,875 of them had sabres, which is $47 \%$ soldiers $^{22}$. It should be noted that popularity of sabres differed across the troops. So in the captain Wacław's troop registry lists 167 blade weapons, of which 133 are swords. On the other hand, in 10 out of 16 troops

22 It's hard to agree with opinion that the lack of widespread presence of such weapons [sabre] before the $16^{\text {th }} \mathrm{c}$. Kwaśniewicz 1993, 23. 


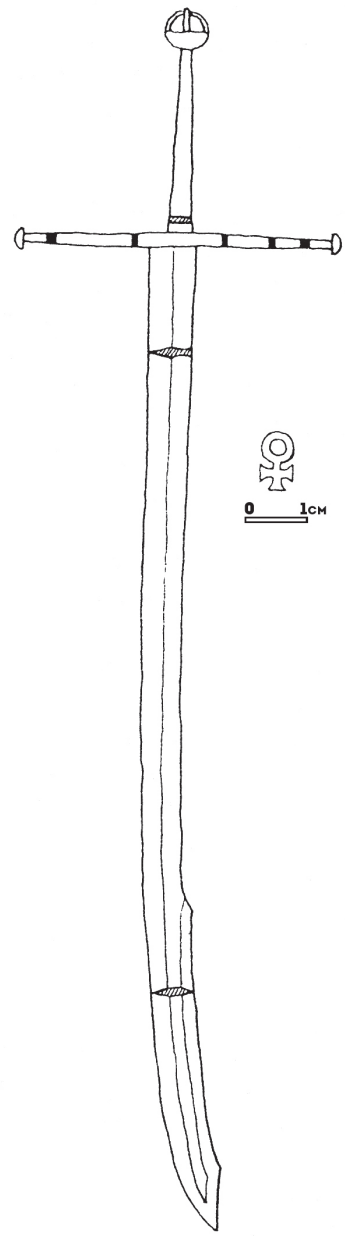

Fig. 1. Sabre found in the river Narew in Pultusk, second half of $15^{\text {th }}$ c. Collection of Museum of Mazovian Gentry in Ciechanów. After Głosek 1992.

which were recorded in the registers of 1471, soldiers more often used sabres (see table). Sabres prevail also in same year register of weapons lost by the soldiers of captain Marek. According to the register, 15 sabres and only 1 sword were lost $\mathrm{t}^{23}$. Popularity of sabres among infantrymen is confirmed by the list of the lost weapons drawn up during the expedition of the Polish army to Silesia in 1474. This list reported 16 sabres and only 3 swords ${ }^{24}$. Usually, sabres were mentioned very briefly and there was only information that the soldier had such weapon. Occasionally, more detailed information is provided. It is mentioned twice that the soldiers had „new" sabres ${ }^{25}$. It was noted only once that the soldier's sabre was rusty ${ }^{26}$. Record from the registry of Maciej Pławecki's troop is worth mentioning. A soldier who served in it, Stanisław Wierzbicki was armed with a sabre named rakuska (=from Rakusy) ${ }^{27}$. The name derived from the town Rakúsy (Raabs) in Austria, located near to

\footnotetext{
23 RK 16, c. 105v, 152-155.

ASK 86/1, c. $38 \mathrm{~V}-43$.

RK 16, c. $11,16$.

RK 16, c. 16v.

RK 16, c. 20.
}

border with Czech. In Poland, in the $15^{\text {th }} \mathrm{c}$. term Rakuski was equivalent of Austrian $^{28}$. It is not known if mentioned rakuska sabre differed from the others ${ }^{29}$. Papers concerning mercenary troops, particularly infantry, show great popularity of sabres already in the 70 s of the $15^{\text {th }} \mathrm{c}$. Unfortunately, there is much less information about the sabres in equipment of mercenary cavalry. Very few records suggest that the sabres were used rather by lightly armored riders ${ }^{30}$.

\section{Falchion}

Another type of blade weapon used by mercenaries was a falchion. It's length, usually about $70 \mathrm{~cm}$, led scientists to classify it on the borderline between short and long melee weapon $^{31}$. Falchions are considered as typical weapon of plebeians, though, it was also used by nobility. Given the fact that the mercenary infantry consisted mostly of plebeians, it may seem strange that we find only 9 records of this type of weapon in the registers ${ }^{32}$. Even less is known about the use of falchions by mercenaries from horse units. In 1454 captain Mikołaj Chrząstowski received a payment of 5 guilders for 2 crossbows, a sword and a falchion. In this case, the falchion could serve as an additional equipment apart from the sword. It is also possible that the cord was bought for a soldier serving in his retinue.

Registers of mercenaries do not support the view that falchions in late medieval Poland were very popular. Neither registers of weapons, for example guild or urban, contain information about falchions. Despite the low price that did not exceed 8 groses for a falchion, this weapon clearly was less popular than expensive swords and sabres ${ }^{33}$. So it seems that falchions could have been popular as personal, everyday weapon for less affluent ones. However, professional soldiers preparing to participate in the war favored other types of weapons.

\section{Estoc}

On the borderline between blade and stabbing weapons is an estoc which appears in Polish sources as koncerz or granat ${ }^{34}$. A characteristic feature of this weapon was the blade - a narrow, rigid, of triangular or rhomboid crosssection. With such a construction it perfectly pierced plates of armor. Estoc was already known in the mid-thirteenth

28 Stownik staropolski 7, 1973, 43.

29 It is known that at the end of the $15^{\text {th }}$ and beginning of $16^{\text {th }}$ c. was known in Poland several types of sabres. From year 1506 comes mention of Tatar saber (framea tartarica), from the later period also mention of the Turkish saber (framea thurecka) and Cossack saber (framea koszacka). Szymczak 1989, 73.

30 Grabarczyk 2015, 78-80.

31 Szymczak 1992, 120.

32 Księga żołdu, 65.

33 Cost of falchion in the $15^{\text {th }} \mathrm{c}$. was $4-5$ groses - Nadolski 1984, 71; Szymczak 1989, 71.

34 Swaryczewski 1982, 35-48; Szymczak 1989, 68; Nowakowski 1994, 204. 
century, however it became really popular only in the next century together with dissemination of plate armor in Europe. In Poland estocs were used probably already in the $14^{\text {th }} \mathrm{c} .{ }^{35}$. It can be concluded from the fact that one of a few original estocs in Polish collection dates back to this period. The estoc found in Kalisz, has a blade which is $92,8 \mathrm{~cm}$ ong $^{36}$. The second estoc, stored now in the National Museum in Cracow, was most probably a part of the equipment of the Teutonic Order. Due to large size - blade 134,8 cm, handle $23,5 \mathrm{~cm}$, pommel $6,5 \mathrm{~cm}$ - it can be assumed it was riders' weapon ${ }^{37}$. In written sources first mention of an estoc dates back to 1466 and concerns weapon of Jan of Sprowa who was a royal official in Lesser Poland (Małopolska) ${ }^{38}$. His estoc was priced at considerable sum of 7 florins $^{39}$. Both the owner, who was a wealthy knight, and the price seem to indicate that it was a weapon designed for a rider. Another mention of an estoc comes from 1471 registers of mercenary infantry. In these lists estocs are very rare. We know only about 10 soldiers who used weapons of this kind. Only in troops of Grzegorz Skladny and Piotr there were two infantrymen armed with estocs ${ }^{40}$. One estoc is mentioned in registers of troops of captains: Grot and Matysz ${ }^{41}$, Marek $^{42}$, Jan Cieniecki ${ }^{43}$, Bartosz ${ }^{44}$ and Niemczycki ${ }^{45}$. In the troop of Mikolaj Brożyna served Irzyk whose estoc was described as small ${ }^{46}$. Apparently, this extremely dangerous weapon did not win many enthusiasts among mercenary infantry, presumably because of a high price. Estoc does not appear in the records of the mercenary cavalry ${ }^{47}$.

\section{Daggers}

The daggers, short blade weapon, appear nine times in the registers of mercenary infantrymen, In all cases, it was the only blade weapon owned by its owners. The first dagger in registers appears under the name tylec ${ }^{48}$. This term comes from German Dolch and Tulich and appears in Polish sources already in 1453. It is assumed that the name means a single-edged combat $\mathrm{knife}^{49}$. Price range of this type of weapon was large. It was possible to buy tylec for 18 groses, however, there is a case when the weapon was valued up to 3 florins ${ }^{50}$. The differences probably resulted from the method of making the handle.

Another type of the dagger appears under the name burderzs. Six infantrymen had such weapons in $1471^{51}$. In Polish sources, first mention of this weapon dates back to 1436. Its Polish name derives most probably from Czech language which includes the word burder ${ }^{52}$.

In literature there is an opinion that the Czech term can be associated with French boudelaire, from which we derive the term baselard. Due to its name, the weapon is believed to originate from Basel $^{53}$. You can not agree with another assumption according to which burderz meant parrying dagger - weapon held in left hand, used to parry while in the right hand was held a rapier ${ }^{54}$. The weapon called kordzik-little falchion is a type of a handgun. This is a single-edged weapon, called sometimes combat knives ${ }^{55}$. Only four infantrymen armed with the weapon were reported ${ }^{56}$. The weapon called mieczyk - a little sword appears only once in the records of infantry ${ }^{57}$. We know daggers which resembled swords both in the shape of the blade and the crossguard, being daggers' miniature. Its length reached up to $50 \mathrm{~cm}^{58}$.

Information included in the registers of mercenary troops, mostly infantry, prove variety of melee weapon used by soldiers in 1471 . According to the lists, most popular among infantrymen were sabres and swords, as far as other types of weapons are concerned we may say they were used by mercenaries occasionally. The most important conclusion which can be drawn from the analysis of the content of registers, is that swords, so popular in Poland in the $16^{\text {th }} \mathrm{c}$., had already been in common use in the second half of the $15^{\text {th }} \mathrm{c}$.
35 Głosek 1998, 120.

36 Nadolski 1984, 73.

37 Żygulski 1982a, 98.

38 Jan of Sprowa was Master of the Pantry in Sandomierz and capitaneus of Samborz (subdapifer Sandomiriensis and capitaneus Samboriensis).

39 Szymczak 1989, 69.

$40 \quad$ RK 16, c. $65,66 \mathrm{v}, 113,113 \mathrm{v}$.

41 RK 16, c. $2 \mathrm{v}$.

42 RK 16, c. $95 \mathrm{v}$.

43 RK 16, c. 10.

44 RK 16, c. $68 \mathrm{~V}$.

45 RK 16, c. 107.

46 RK 16, c. 16v.

47 Grabarczyk 2015, 78-80.

48 RK 16, c. 70v; Księga żołdu, 74.
49 Kiryk 1972, 280; Szymczak 1989, 75; Szymczak 2005, 389.

50 Szymczak 1989, 75.

51 RK 16, c. 99, 112v-113; Grabarczyk 2000, 122-123.

52 Brückner 1894, 315; Stownik staropolski 1 (1953-1955), 177; Szymczak 1989, 74; Szymczak 2005, 390.

53 Marek 2008, 26.

54 Kwaśniewicz 1981, 29, 100-101.

55 Marek 2008, 27-29.

56 RK 16 , c. $5.7 \mathrm{v}, 98,103$.

57 RK 16 , c. 8.

58 Nadolski 1971, 679-681; Żygulski 1982b, 111, Pic. 52 daggers signed simbols: $k$ and $m$. 


\section{Sources}

ASK 86/1 - Archiwum Akt Dawnych w Warszawie. Archiwum Skarbu Koronnego 86/1.

RK 16 - Archiwum Akt Dawnych w Warszawie. Archiwum Skarbu Koronnego 1. Rachunki Królewskie 16.

Księga żołdu - Księga żołdu Związku Pruskiego z okresu wojny trzynastoletniej 1454-1466, ed. A. Czacharowski. Toruń 1969. Żywot człowieka poczciwego - M. Rej, Żywot człowieka poczciwego, ed. J. Kallenbach. Warszawa 1903.

Rejestr 1521 - Rejestr wozów skarbnych od miast i miasteczek Rzeczypospolitej koronnych na wyprawę wojenna roku 1521 dostarczonych, ed. C. Biernacki. In: Scriptores rerum Polonicarum 9. Kraków 1886, 473-498.

Brückner - A. Brückner, Średniowieczna poezyja łacińska w Polsce. part 3. „Rozprawy Akademii Umiejętności” F. ser. 2. vol. 8 (23), 1894, 315.

\section{Bibliography}

Głosek M. 1984. Miecze środkowoeuropejskie z X-XV w. Warszawa.

Głosek M. 1992. Przyczynek do dziejów szabli w Polsce. In: M. Głosek (ed.), Arma et olae. Studia dedykowane Profesorowi Andrzejowi Nadolskienu w 70 rocznica urodzin i 45 rocznica pracy naukowej. Łódź, 63-69.

Głosek M. 1998. Broń biała. In: A. Nowakowski (ed.), Uzbrojenie w Polsce średniowiecznej 1450-1500. Toruń.

Górski K. 1893. Historya piechoty polskiej. Kraków.

Grabarczyk T. 2000. Piechota zaciężna Królestwa Polskiego w XV wieku. Łódź.

Grabarczyk T. 2015. Jazda zaciężna Królestwa Polskiego w XV wieku. Łódź.

Kiryk F. 1972. Cechowe rzemiosło metalowe. Zarys dziejów do 1939 r. Warszawa.

Kwaśniewicz W. 1981. 1000 słów o broni białej i uzbrojeniu ochronnym. Warszawa.

Kwaśniewicz W. 1988. Szabla polska od XV do końca XVIII wieku. Zielona Góra.

Kwaśniewicz W. 1993. Pięć wieków szabli polskiej. Warszawa.

Marek L. 2008. Broń biała na Śląsku XIV-XVI wiek. Wrocław.

Masarykův slovník naučný. Lidová encyklopedie všeobecných vědomostí 7. Praha 1939.

Nadolski A. 1954. Studia nad uzbrojeniem polskim w X, XI, XII w. Łódź.

Nadolski A. 1971. Sztylet średniowieczny znaleziony w m. Orzeszyn, pow. Grójec. „Archeologia Polski” 16 (1/2), $679-681$.

Nadolski A. 1984. Broń polska. Broń biała. Wrocław.

Nowakowski A. 1994. Uzbrojenie indywidualne. In: A. Nadolski (ed.), Polska technika wojskowa do 1500 roku. Warszawa, 198-249.

Senkowski J. 1954. Materiały archiwalne do historii organizacji polskiej siły zbrojnej w drugiej połowie XV wieku przechowywane w Archiwum Głównym Akt Dawnych w Warszawie. „Studia i Materiały do Historii Wojskowości” 1, 497-521.

Stownik staropolski 1. Warszawa 1953-1955.

Stownik staropolski 7. Wrocław 1973.

Stownik staropolski 8. Wrocław 1977.

Swaryczewski A. 1982. Granat-sztuka mistrzowska stradomskiego cechu mieczników. „Studia do Dziejów Dawnego Uzbrojenia i Ubioru Wojskowego" 8, 35-48.

Szymczak J. 1989. Produkcja i koszty uzbrojenia rycerskiego w Polsce XIII-XV w. Łódź.

Szymczak J. 1992. Ceduła na sąd boży z 1511 roku. „Acta Universitatis Lodziensis. Folia Historica 44”, 111-125.

Szymczak J. 1998. Ceny broni, koni i oporządzenia jeździeckiego. In: A. Nowakowski (ed.), Uzbrojenie w Polsce średniowiecznej 1450-1500. Toruń, 225-289.

Szymczak J. 2005. Nóż i sztylet, czyli misericordia na polu walki w średniowieczu. „Archeologia Historica Polona” 15 (1), 383-396.

W[ójcicki] K.W. 1867. Szarszun. In: S. Orgelbrand (ed.), Encyklopedyja powszechna, vol. 24. Warszawa, 560.

Żygulski jun. Z. 1982a. Stara broń w polskich zbiorach. Warszawa.

Żygulski jun. Z. 1982b. Broń w dawnej Polsce. Na tle uzbrojenia Europy i Bliskiego Wschodu. Warszawa. 


\section{Streszczenie}

\section{Broń biała na uzbrojeniu zaciężnych Królestwa Polskiego w drugiej połowie XV wieku}

Źródła z drugiej połowy XV w. zawierają wiele informacji o uzbrojeniu wojsk zaciężnych Królestwa Polskiego. Materiały te znajdują się przede wszystkim w Archiwum Akt Dawnych w Warszawie. Są to głównie spisy przyjmowanych na służbę żołnierzy wraz z ich uzbrojeniem oraz wykazy broni utraconej w trakcie działań wojennych. Na wzmianki o broni białej natrafiamy także w rachunkach z okresu polsko-krzyżackiej wojny trzynastoletniej z Zakonem (1454-1466). Najwięcej informacji dotyczy piechoty - w spisach z 1471 r. odnotowano 1880 żołnierzy z bronią białą. Jak wynika z przeprowadzonej analizy najpopularniejszą bronią sieczną były wówczas miecze, używane przez 51\% żołnierzy. Niewiele ustępowały im szable, które w 1471 r. miało 47\% piechurów. Sporadycznie zaciężni wyposażeni byli w kordy, koncerze, puginały oraz szarszuny, którą to nazwą określano ciężki miecz. W źródłach dotyczących jazdy broń sieczna pojawia się sporadycznie. Na podstawie tych nielicznych wzmianek można jedynie stwierdzić, że jeźdźcy używali zarówno mieczy, jak i szabel. 
